\title{
NOT BUILT TO LAST: Military Occupation and Ruination under Settler Colonialism
}

\author{
JOSEPH WEISS \\ Wesleyan University \\ (D) https:/ / orcid.org/0000-0001-8216-222X
}

It took a long time for the swimming pool to close in the Village of Masset. The pool had been the single most important feature of Masset's recreation center, which the community had inherited when the military base was decommissioned in 1997. But the only way to heat the pool was with diesel fuel, and by 2013, that had become cost-prohibitive for the Greater Masset Development Corporation, an organization administered jointly by the settler village of Masset and their immediate neighbors, the Haida First Nations community of Old Massett. Left without any other option, the communities shut down the pool and closed the recreation center for good. Only the shell of the building remained, the last remnant of Canadian Forces Station Masset (CFS Masset), left hollow and abandoned in the center of town.

The shuttering of the rec center appeared to many in both Masset and Old Massett as an unhappy epilogue to more than fifty years of sustained military presence on the islands of Haida Gwaii, ancestral home and unceded territory of the Haida Nation. The Base, as CFS Masset was popularly known, was gone, and with it all the resources it had brought to the two communities. Other than ruins, all that remained was a radio outpost a few kilometers north of Masset, which, people believed, was remotely operated. Except, as Marlene Liddle and her family dis- 
covered, the military had not gone from Haida Gwaii. One day in July, when the Liddle family was out berry picking on their traditional territory, they- to their surprise - discovered a sign on their recently renovated outhouse. The sign, written and placed by a member of Canada's Department of National Defense (DND), informed the Liddle family that their outhouse had been built on DND land and was thus an "illegal building, . . . built without the approval of the Minister of National Defense, and violated [sic] the Canadian Environmental Protection Act." Unless the family took down the offending building, the note informed them, it would be "removed on their behalf."

And yet, the offending outhouse was not new, even if it had been newly renovated. Indeed, one incarnation of the outhouse or another had stood in this same place for the past fifteen years. The military had been notorious for interfering with Haida resource gathering on land the DND had claimed as its own, and Marlene Liddle and her family had wasted little time in returning to berry picking and other forms of food gathering when the military ostensibly left in 1997. There had been material evidence of that departure, moreover: By 2011 the buildings that had made up the Base had been in gradually decay for more than a decade and most of the remaining facilities had been shut down. Even the "private married quarters," mid-sized houses built for military officers and their families, had been sold to Masset's residents as civilian housing. The ruins of the Base provided a material reminder of the military's absence, their skeletal frames signaling Masset's post-military present to residents and new arrivals alike. It was community common sense, in short, that the military was gone for good. As, it turned out, however, that absence was an illusion, or perhaps even a deception.

What does it mean when ruins lie? In his ethnographic exploration of the afterlives of material and social destruction in Argentina, Gastón R. Gordillo (2014, 10) characterizes the rubble left behind by the multiple histories of conquest and violence in the Chaco as "the material sedimentation of destruction." A focus on rubble, Gordillo $(2014,11)$ argues, allows us to "examine space negatively: by way of places that were negated to create the geographies of the present." As Gordillo (2014, 207) makes clear throughout his ethnography, such acts of negation are productive, making possible particular political, social, and temporal realities via the "material and affective erasures of traces from the past," most often "shaped by orders to remember given by dominant social actors." Destruction, then, is a performative action, a means of making erasure real, and the rubble left behind acts as a "topography of oblivion" for these ongoing social projects of selective memory (cf. Trouillot 1995). Put more simply, to destroy material traces suggests 
that those who inhabited said matter are, themselves, gone. Such modes of "ruination,” as Yael Navaro-Yashin $(2009,5)$ has argued, leave profound and often deeply ambivalent affective traces — "the subjectivities and residual affects that linger, like a hangover, in the aftermath of war and violence," as she elegantly puts it. Humans, these authors argue, feel haunted by what has come before, the ghostly doubling of an effaced past that has constituted the present by its absence but has not, at the same time, truly disappeared (cf. Leathem 2019).

Except, on Haida Gwaii, the military never actually left. This does not mean that both Haida and non-Haida did not experience the military as gone; quite the opposite. As I will show, the military's departure and the subsequent erosion of its seemingly abandoned facilities generated a series of affects that resonate with Gordillo's (2014) and Navaro-Yashin's (2009) accounts of ruination. Indeed, this is precisely the point. Ruination made it appear as if the military had left Haida Gwaii, concealing the fact that the army was still actively occupying Haida territory. This, I argue, is no coincidence. Rather, what we find at work here is the deliberate production of a paradox, in Kanaka Maoli scholar J. Kēhaulani Kauanui's (2018) sense: a constitutive contradiction that serves to reinforce the structures of settler domination even as it seems to mitigate the visible presence of the force-and the forces - of occupation. By erasing the overt forms of military power, colonial governments thereby render covert the ongoing maintenance of settler domination.

My goal in this article is to hold together the very real affects of ruination on the part of Haida people with the contention that this ruination constituted a deliberate and deceptive means through which a particular kind of military presence disguised the ongoing quality of its occupation of Indigenous territory. I begin with the Base itself, situating CFS Masset in the history of Haida Gwaii, with a particular focus on the experiences of Haida people. I then turn to the idea that, despite its seeming permanence, the Base was "not built to last," as one former employee put it. Instead, the military adopted a series of strategies designed to mitigate the possibility of its personnel forming durable relationships with Haida people or, to an extent, their settler neighbors. In this, I take the ruination of the swimming pool as my central, epitomizing image. Drawing on Ann Laura Stoler's (2016) compelling formulation of "imperial durabilities," I query the nature of these paradoxical durabilities, keeping in mind the particular irony that CFS Masset's occupation of Haida land was, from a military perspective, an almost incidental epiphenomenon of the need to maintain radio surveillance during the Cold War. Finally, I return to the Liddle family's "illegal outhouse," suggesting that the military's continued presence on Haida Gwaii despite its performance of departure 
offers us a potent metonymy for the shifting means through which settler-colonial states such as Canada conceal the violence that remains at the heart of their ongoing occupation of Indigenous territories.

\section{"THREE COMMUNITIES"}

I first became interested in the legacy of the military base in the Massett area during a conversation with David Armstrong, ${ }^{2}$ a well-respected senior member of Old Massett's community. ${ }^{3}$ We'd been talking “on the record" about changes in the Haida community for a dozen or so minutes when Armstrong turned the conversation to the Base:

DA: I mean, when I was growing up around 1970, the military showed up. I mean the military was always here, but small scale, and all of a sudden there were three thousand of them. So it made it three communities instead of two, and they drove the wedge in more, well, I guess we all did cuz it's, when they had the rec center and they had their own CANEX, the food store.

JW: Yeah, I remember hearing about that, that they had their own grocery store that no one else could use.

DA: Unless you worked for them or else you were military and that, that was hard on the kids cuz, I mean, all these kids were going to the gym and swimming pool and if your parents didn't work for them, you couldn't go. And that really segregated the place.

JW: Yeah, that's really rough.

DA: And the military, the first thing they were told when they arrived here is they're not to go down to the village.

JW: Huh.

DA: So, and that, I mean, they've downsized them quite a bit and it's changed, it's back to two communities now, not three [emphasis added].

Armstrong's concise narrative of the social changes brought by the military reconfigured my understanding of the social terrain of the two Massetts. The "settlers" of settler colonialism were not, for Armstrong, a homogenous mass, a single, cohesive body to be endured by the Haida. Instead, when the military "showed up" - and note again the fact that even before soldiers arrived en masse, the military "was always here" - it made "three communities instead of two," interposing itself between the Haida of Old Massett and the historically settler community of the Village of Masset. 
Relationships between the two communities were already segregated before the establishment of CFS Masset in the Village of Masset. Haida Gwaii has been Haida territory since time immemorial, but living conditions underwent a fundamental transformation in the late nineteenth century with the arrival, on the one hand, of settler missionaries and, eventually, homesteaders, and the decimation by epidemic diseases such as smallpox, on the other. Haida are matrilineal, with territorial and resource rights allocated to individual matrilineal clans and adjudicated through the feasts now commonly glossed as "potlatches" (e.g., Collison 2011; Bell 2016). ${ }^{4}$ Yet the reserve allocation process in British Columbia ignored clan rights, superimposing colonially mandated boundaries in perpetuity over a flexible system of inter-clan territorial negotiation. The reserve of Old Massett was thus by definition a hybrid space when officially constituted by British Columbia's Joint Reserve Commission in 1882, composed of the survivors of many different clans who had joined together in a single, central location so as to survive (Weiss 2018, 7). The creation of these reserves on Haida Gwaii was justified, as elsewhere in British Columbia, by the assertion that the islands had been claimed as Crown land and that Canada, as the Crown's representative, had jurisdiction over the lands and lives of Haida Gwaii's Indigenous population - this although no treaties had been signed (or even proposed) and their Aboriginal Title had never been extinguished. Nonetheless, the Haida communities were allocated small patches of land on their ancestral territory and expected to allow for colonial settlement and resource extraction throughout the islands. ${ }^{5}$

The Village of Masset was founded a few decades later by a group of settler homesteaders who appropriated territory just a few kilometers east of the reserve. Even the village's name represents a kind of founding theft, as I have chronicled elsewhere:

In 1907, when the site for the future settler village was first surveyed, the town site was given the name Graham City. However, when the city planners discovered that the postmaster for the Haida community then called Masset was leaving, they applied for a post office in their townsite and claimed its name was Masset. Effectively, the city planners had stolen both the post office and the name Masset from their soon-to-be neighbors. (Weiss 2020, 67)

What followed over the course of the twentieth century was the systematic establishment of settler domination over the island's resources and territories. Alongside the centralization of services in the settler community and the regular refusal 
by most banks and businesses to serve "Indians," settler fishermen monopolized control of commercial fishing, establishing themselves as leaders of fishing crews that, at best, included Indigenous employees, and attempted to push independent Indigenous fishermen out of business (see Stearns 1981; Weiss 2018, 53-57). ${ }^{6}$ This was the landscape in which Armstrong grew up, and the social world where the military "showed up" in the late 1960s.

The Base opened with a lavish ceremony in 1968, at least in the form that Armstrong's generation remembers. Yet "the” Base was not, strictly speaking, the first military base on Haida Gwaii. Instead, the Base's first incarnation was $\mathrm{Na-}$ val Radio Station Masset, established during World War II and operated directly within the Old Massett reserve as a relatively minor naval listening station aimed primarily at the Pacific theater of operations. But the Base proved different when it was (re)opened. While it retained its function as a listening station-albeit one now firmly entrenched in the geopolitics of the Cold War-the new Canadian Forces Station Masset was heralded at the time as also inaugurating a major transformation in military-civilian relations in Canada. It was to be the first "open-concept" military base in the country, "devoid of fences and sentries" and, instead, "enmeshed" in the life of both Masset and Old Massett (McMullen 1998, 3). And enmeshed it very quickly became. At its peak of operations in the 1970s, the Base included almost three hundred military personnel split between barracks - the core of the ruins post-1997 — and the aforementioned private married quarters, built in residential circles near the Base's primary facilities. These houses, typically two storied affairs with nicely painted exteriors, spread out around the Base in miniature neighborhoods, offering an almost suburban veneer to the barracks' stark brown walls and flat, squat roofs.

The Base provided employment for many, developed local infrastructure, acted as a local hospital, and hosted leisure activities like dances, arts and crafts groups, and community events. Indeed, the very layout of Masset as I encountered it was shaped by the presence of the Base, its residential circles radiating out from the center where the Base once sat, with easy proximity to the local elementary school (constructed, I learned, with military support to house Haida and nonHaida students along with the children of military personnel). Even the asphalt roads that connected the Masset area to the southern towns on Haida Gwaii's largest island were laid by the military, a road that passed by the golf course put in by the military for recreation. And while there might not have been fences, the military was ubiquitous, patrolling "its" territory and making sure that "intruders" - particularly local Haida resource-gathering_-were quickly removed. ${ }^{8}$ 
As Armstrong details, with these transformations came shifts in the forms of segregation - the "wedge," as Armstrong puts it - already present between the Indigenous and settler communities on the island. The modes of division that the Base brought unfolded in parallel with these already ongoing dynamics, but their terms proved distinctive: If someone worked for the Base they and their family had access to discounted groceries, military dining messes, programming aimed at military families, and, of course, the rec center and its facilities, especially the all-important swimming pool. And many Haida did indeed work for the Base. ${ }^{9}$ Over the course of my research, I spoke with former cooks and drivers, former janitorial workers, and even former radio operators, all of whom formed part of the substantial support staff that the Base relied on to operate at its peak. Many Haida elders that I have known draw military pensions for this work.

These facts mean that the terms of inclusion and exclusion from Armstrong's three communities might be more complicated than they first appear. While his initial two communities seem to map fairly coherently onto the categories of Indigenous and settler, ${ }^{10}$ the fact that the privileges carried by the military extended to their non-military employees makes such binaries messy. ${ }^{11}$ It meant that some Haida had access to facilities that other Haida did not; so too, some Haida shared that access with some of the non-Haida residents of Masset who were also working for the Base. Likewise, some Haida shared with their non-Indigenous neighbors the absence of privileged access - more expensive groceries, fewer (if any) recreational facilities, no space to teach their children to swim. Note Armstrong's discursive shift as he tells the story: "And they drove the wedge in more," meaning the military, transitions to "well, I guess we all did," distributing the responsibility for community polarization among all three categories of actors-Haida, settlers, and military.

Armstrong was not the only person to elaborate on these tensions. Consider, for instance, how divisions over the military in the Haida community emerge in Haida artist and political leader Fred Willis's comparison between life now and life with the Base:

FW: Like I said, eh, there's more sense of freedom again, being able to walk where you want, when you want. You go do your seasonal things in that area, ... which I've been doing and I never did stop, even though they came after us, I never did stop. I always reminded them, "you're on Haida territory, it's Old Massett's territory you're on." They never understood that kind of thing, because they'd never dealt, a lot of them had never dealt with First Nations 
before, let alone stepped on somebody's territory, and had somebody say something about it without due process, eh? Ask first, that kind of thing. So. JW: Which makes a lot of sense. So, like, would they ever, I'm just thinking in terms of resource-gathering, would they ever intervene when elders were out gathering?

FW: Yeah, it didn't matter who it was. Their orders were to go out and remove people from that area, and so they did. So yeah, some of our elders were - that's when we really, really started to hear about it, more often than not, was because the elders were the ones who were most upset about it.

JW: Yeah.

FW: And then of course there were some that would, that, you know, basically joined them, if you will, eh? Like did and said and worked with them, and so they were side by side, a lot of them, and so now we have Haidas on that side and Haidas on this side, so it created a conflict for sure, for sure. Plus they took our women! That's why I say it's now a little more serene for me, anyway.

Willis begins with a confident assertion of Haida sovereignty in the face of military occupation and his own commitment to resource-gathering even when faced with opposition from the Base. "Even though they came after us, I never did stop." Haida sovereign rights, for Willis, necessarily entail the right of Haida to gather resources on their clan's territories and to retain the power of permission over who can and cannot gather on Haida land; to disrupt these rights marks a violation. "Ask first, you know?" Indeed, in the face of this opposition, Willis remembers reiterating Haida territorial sovereignty to these invaders, whom he figures as disconnected from any experience with Indigenous communities in general, much less any specific knowledge about or respect for the Haida people whose lands they were occupying.

And yet, as he continues, Willis turns to the Haida who "basically joined them," those who worked with and stood by the Base's employees even as, in Willis's view, Haida elders in particular were impacted by the military's refusal to allow them to gather resources or even simply to be present on their traditional territories. Unlike the military, who "never understood that kind of thing," these Haida, presumably, would have "known better," and yet chose to ally themselves with, in Willis's reading, the agents of military occupation of their own land. Here the clear lines of "us" and "them" break down, as different Haida position themselves and are positioned separately in an ongoing space of at least imminent con- 
flict. This sense of division held as much true for Haida who worked for the Base as it did for Willis and those who shared his position. Former Haida Base employees with whom I spoke expressed to me their frustrations with friends and family who didn't understand their choice of employment or, even more distressingly, resented the financial benefits and privileged forms of access that military employment brought. Some friends even recalled seeing physical altercations between Haida on different sides of this divide. ${ }^{12}$

We also should not neglect Willis's exclamation near the end of the excerpted conversation. "Plus they took our women!" One of the most dramatic and yet simultaneously most intimate consequences of the sustained presence of military officers were the relationships - and sometimes marriages - that developed between military personnel, their families, and Haida community members. As Willis emphasizes, there were, and are, undeniably gendered dimensions to these discourses, with the narrative of "theft" in particular mapping onto older, typically colonial, and certainly problematic discourses that frame women as men's possessions. ${ }^{13}$ And yet, men as well as women made frequent reference to intimate and sexual relations with military folk as a major axis of Haida-Base sociality (cf. Enloe 2000). One reason for this, as I heard frequently, was to avoid intimate relations with kin. Haida clan and moiety membership is reckoned matrilineally, and the Eagle and Raven sides are formally exogamous. As my friends pointed out — sometimes in jest, sometimes seriously - entering into a relationship with a military officer or their children guaranteed you wouldn't wind up "dating your cousin," considerably opening up the field of potential partners, both casual and long-term.

The impact of the Base means that, on Haida Gwaii at least, the boundaries between inclusion and exclusion did not devolve comfortably into clear lines between Indigenous and settler, between Native and military. Whether one reads the Haida people who worked with the Base as co-opted by it, as Willis intimated, or follows the opposing position that those Haida who did not work with the Base were jealous of the resources it offered to employees, as others suggested to me, we arrive in each case at the Base as a complex site of relationality, striated by flows of power, by access and exclusion, and by gender and intimacy. In these senses Haida experiences with the Base echo ethnographies of other military bases as close to Old Massett as North Carolina (Lutz 2002) or as far as South Korea (Schober 2016).

At the same time, that Armstrong nonetheless characterized the islands as divided into "three communities" matters. Real and ongoing pressure existed to keep the three communities conceptually apart, even if they could not be sep- 
arated economically or socially in any real material sense. Even the Haida people that did have connections to the Base through their own work or that of a family member sometimes found themselves excluded from military-sponsored events and organizations through the force of social pressure and hostility, echoing the forms of segregation that Haida already experienced in settler Masset. Many who had lived through the military era felt that the bars were not safe, and they were often characterized as the primary spaces where fistfights between Haida and army personnel broke out. The antagonisms were regularly ritualized in local sports events, in particular the annual tug-of-war challenges that were a fixture of my conversations about life during the Base era. In these "games," participants were separated into Indigenous, military, and Masset resident teams, formalizing Armstrong's three communities not only as socially visible but in a sense also as implicitly obvious. Such performative attempts aimed to clarify the murky, grouping communities into clear and legible lines even as their forms of sociality cut across them in complicated, intimate, and uneasy ways.

\section{"POOF, IT WAS ALL GONE"}

While very little may have been simple about the entanglements of military, civilians, and Haida during the Base era, one thing seemed obvious to most Haida and settler civilians: the Base was there to stay. It is not difficult to understand why this would be the case. The military paved the roads, provided medical services, built a school, radically expanded the infrastructure of Haida Gwaii's north end, and even put in a golf course. It engaged in the ongoing, material, and irreversible transformation of Haida Gwaii's landscape. So, too, its social landscape was reshaped simultaneously by military employment, the privileges of CANEX and rec center access, and the more intimate ways through which military personnel were building relations (and sometimes families) with Haida people. The presence of the military thus appeared durable in Stoler's (2016) sense, a "hardened," "tenacious," and "enduring" fact of life on the islands. Imperial durabilities, as Stoler explores, are charged with suffering, but they also speak to the ways that subjects of empire can "endure" against ongoing colonial violence and domination, and the "damage and disability" that it brings with it (Stoler 2016, 7). Dealing with the Base made for an inescapable, ongoing reality for Haida people, whether they were navigating the opportunities it afforded or experiencing the many constraints and limitations the military imposed.

And then, in 1997, CFS Masset was decommissioned and the military "left."14 While this might have been an untampered relief for those Haida like Willis who 
had avoided the Base as much as possible, many others met the military's departure with considerably more ambivalence, especially given the speed at which it seemed to occur. Daniel Montgomery, the son of a Haida woman and a non-Haida military officer, found the ambivalence especially sharp. Though his parents had met on Haida Gwaii, Montgomery did not spend his earlier years there. Effectively, he could not have: not only did military deployment rules mean that army families had to move every few years (a point to which I will return in detail), but the terms of Canadian Native law before the 1980s meant that, because of her marriage to a non-Haida man, Montgomery's mother lost her Indian status, and thus her band membership and right to reside on reserve. Only after the end of his parents' marriage when he was a youth did Montgomery come to live on the islands full time. Reflecting on his experiences with the Base, Montgomery shifted affective registers. He spoke with considered enthusiasm about the income the Base brought into the community despite its complications, the ways meeting families from all over the country expanded his own horizons, and the benefits of meeting potential partners who were definitely not his cousins. "I think I was sad to see it go," Montgomery told me. "I enjoyed it, it was a good experience for me, met my first love through the military. . . . So, yeah, I miss it, I think it was a sad thing when that happened."

But, and here Montgomery shifted, "I mean, good and bad; I've had some bad experience with the military." He then told me the story of being detained by military police one evening because he was out walking after dark. Apparently, he later learned, an assault had been reported, and Montgomery, a dark-skinned Haida man walking alone after 10 p.m., seemed to the military police precisely the kind of person to interrogate about the matter. This despite the fact that, from Montgomery's perspective, the military did not have the jurisdiction to detain civilians on such matters. "They were patrolling around the area, and I was in the wrong place at the wrong time. . . . I of course wasn't who they were looking for, but it was quite, really, you guys aren't even police, how can you do this? So we got through that, but it was traumatizing at the time." Crucially, Montgomery noted, the military officers who detained him weren't people that he knew.

As he turned toward the Base's eventual decommissioning, Montgomery's reflections became more critical:

The houses were all still there, but the people who filled the houses weren't there. It was over a couple of years, I guess, but it sure didn't seem to take long for them to move out. . . . Once a decision was made, it seemed like it 
was just, "poof," it was all gone. And then what really seemed to, you know, we always had the barracks, it was kind of sad to see that go, nothing really came out of that, you know? I understand that it was an older building. Like that's almost kind of sad, it's almost like we just got, I'm not going to say left their garbage, but the equipment was old, the swimming pool was old, the barracks was old. So, I guess in that way, it almost feels like we kind of got used, you know, kinda. So that's probably my most negative thing towards it, just saying, "yeah, you came, you saw, you took what you had to take and you just left," and all we got left was some old houses and a run-down barracks that had to be torn down.

Sad to see the Base go, but also sad to see what it had left behind. The military was too "militant," as Montgomery put it, about "defending" what they took to be their territory, but, even more insulting, when it left, it left nothing behind but ruins, material reminders of the lack of commitment to making life better on the islands. Ambivalence can be productive, argue Ciara Kierans and Kirsten Bell (2017, 39), because it "destabilizes the very categories it is built upon." Ambivalence, that is to say, is unsettling, casting critical purchase on the conflicting emotions that constitutes it precisely because the paradox - the military as a force that provided and would be missed, the military as an active agent of violent domination-cannot be resolved.

Montgomery's comments echo the theories of ruination with which we began, aptly embodying the "subjectivities and residual affects" of Haida people dealing with the aftermath of the Base as social phenomenon and material presence. These feelings had their corollary in the rec center's swimming pool, whose maintenance became the predominant fiscal priority of the Greater Masset Development Corporation (GMDC). Founded in partnership between Old Massett and Masset, the GMDC's mandate was to manage the lump sum that the military left to the two communities as part of the Base's decommissioning process. ${ }^{15}$ Over the next decade, it invested a significant percentage of its funds to maintaining the recreation center - and, especially, its swimming pool — as a public facility. This seemed an obvious choice at the time. As I noted earlier, both Old Massett and Masset are fishing communities. Haida people have been fishing for salmon, halibut, and other seafood since time immemorial, and many perceive marine resource-gathering an essential dimension of what it means to be Haida. Fishing income was and remains crucial to many Haida families operating within the settler capitalist economy. Fishing was likewise central for the Haida community's non-military settler neigh- 
bors, who relied primarily on (and monopolized) commercial fishing for much of their community's income. In this context, a controlled environment in which to safely teach children how to swim took on tremendous importance for Haida and non-Haida alike, at the same time as it offered a valuable means of exercise and recreation for the two small towns.

But these facilities were old, as Montgomery emphasized to me. Run down, destined to be nothing but garbage. Eventually, it simply became financially impossible for the GMDC to maintain them, and the rec center was shuttered. Moreover, the efforts to keep the facilities open as long as possible had essentially wasted much of the money that the military had left. All this, and all the frustration, ambivalence, and betrayal that it represented, sedimented the idea that what was left of the Base was mere rubble, without any more value for the community or social significance except as a reminder of a prior era, a "space negated to create the geography of the present," as Gordillo (2014) might put it. This was certainly my experience of the Base when I first began spending time on Haida Gwaii in 2012. I recall walking around the brown, hollowed-out shells of the barracks in the center of Masset and wondering what they could even be, as by then they had been stripped of any identifying labels. When I asked, people referred to the military presence as "a long time ago," a part of the community's history.

\section{"NOT BUILT TO LAST"}

As potent as the appearance of durability was that the Base gave, however, and as resonant and complex were the emotions generated by the Base's decommissioning and its aftermath, what must be emphasized is that these very forms of ruination were anticipated by the military. They were, put simply, part of the design of CFS Masset itself. Take the swimming pool. As Ted Andrews, a former Base employee, told me, none of the military facilities were "built to last." In particular, that the swimming pool relied on a steady source of diesel for its heating meant exorbitant costs without the support of a Department of Defense budget. The military, Andrews explained, didn't think of its facilities as permanent structures - they were constitutively temporary, to be kept as long as their function was needed, but not preserved past that point. The funds given to the communities by the Department of Defense were non-renewable, and the portion that had been sunk (quite literally) into the swimming pool could never be recovered or put to other uses. This is not necessarily surprising. After all, the Department of Defense had (and has) a network of bases throughout Canada, meant to respond to particular threats and needs as necessary. The significance of one station or an- 
other can always be understood as relative to that broader scale of operation. The fact that this necessarily erodes both the spatial and social specificity of military relationships within a given context would, by this logic, be an anticipated consequence of the structure of military durability.

Similarly, while the military presence on Haida Gwaii was, in aggregate, constant, individual military personnel were rarely given permanent postings at the Base. Instead, personnel deployed on an approximately five-year rotation, which meant that, with the exception of some key higher-rank personnel, no soldier resided in the Masset area for more than a few years at a time. ${ }^{16}$ Thus, while the Base itself could be understood as a permanent fixture of the north end of Haida Gwaii, its constantly shifting personnel undercut the possibilities for durable relationality between Haida people and any individual soldiers or their families. These rules applied just as much to personnel with Haida spouses, who had to uproot their lives on the island if they wished to remain with their partners. For the military, then, social relationships, like material structures, were not built to last.

The imperial durabilities of military occupation appear paradoxical here. As we've seen, the military reiterated its presence on Haida Gwaii in the most visible and dramatic of ways, restructuring social and physical geographies alike, meeting elders with guns as they picked berries, arresting young Haida men when they were in the wrong place at the wrong time. Why, then, did the military so systematically seem to emphasize the temporary nature of its own occupation? One answer lies in the nature of occupation itself. The forces of occupation are precisely that, forces, people acting on other people. These people thus contain within themselves the imminent potential to enter into relationships with those they occupy. Because the Base relied on the labor of non-military employees, Haida might be employed by the military for much of their lives, forming durable - and, as we've seen, often fraught - attachments to the military community, even as it acted to deny the sovereignty of Haida actors on their territories. Such modes of attachment are developmental, even linear, building and growing as relationships are made, attachments formed, and social (and physical) worlds transformed. There is a mutuality here, one that might make it difficult, for instance, to bring one's firearm to bear on a grandmother by her berry patch. The structures of military deployment cut against this form of durability, consistently reforming the social composition of the Base's personnel so that, while the institution remained - including the ways in which Haida were recruited to it - individual relationships between Haida and non-Haida would always be temporary. The social content of occupation is perpetually foreclosed even as the material fact of occupation is, just 
as perpetually, reinforced. That is to say, the actual social relations that constitute military relationships with the Haida - and by definition form the social terrain on which occupation occurs - are eroded and erased so that, in turn, military violence can be wielded against Indigenous community members. Indeed, the rendering absent of military presence could even be understood to reinforce this power, offering us (the fantasy of) a de-spatialized and non-social military force that can operate anywhere without any ongoing commitments to the peoples or communities against which it operates.

Imperial durabilities, then, need to be carefully managed, because affective ties, social relations, kinning, and all the other ways in which military personnel, Haida people, and their settler neighbors build community together are also durable, at least in potential, and can rupture such fantasies of military totality. The very fact that people like Montgomery experienced ambivalence at the military's departure points to this. Undercutting these social durabilities requires what we might almost think of as a premeditated plan for ruination, an anticipated foreclosure that leaves no space for ongoing relationality. The military was always going to leave, even as they made it appear they were there to stay. Except, as Marlene Liddle and her family discovered, the military did not, in fact, ever give up its occupying presence on Haida Gwaii.

\section{“THE ROT REMAINS"}

One of the central concerns of Stoler's recent study, Duress, is to push against too great an emphasis on essentially immaterial representations of traces and hauntings in histories of the (post)colonial present. "The scholarly romance with 'traces," she writes, "risks rendering colonial remnants as pale filigrees, benign overlays with barely detectable presences rather than deep pressure points of generative possibilities or violent and violating absences. The 'haunting' trace seems too easily unmoored from material damages and disseminated landscapes" (Stoler 2016, 4-5). Imperial formations, for Stoler (2016, 7), have a "hardened, tenacious quality," meaning they endure in material, affective, and social ways in even seemingly "liberated" contexts. As she puts it, borrowing from the work of the Caribbean poet Derek Walcott, even as the physical and social structures of imperialism might appear to decay, the "rot remains" (Stoler 2016, 338-39).

We can take this provocation quite literally on Haida Gwaii. Despite the ruination of CFS Masset, the military remained on the islands and continued to monitor the territory it claimed as its own. Yet a shift in approach had occurred with the closure of the Base. I was told on a number of occasions that the military 
personnel who remained on the island had been explicitly ordered not to wear their uniforms, effectively "blending in" with the local population. These claims came from local residents and former Base personnel, not active-duty officers, so they exist at the level of local rumor rather than military policy. ${ }^{17}$ Nonetheless, the idea that the military had remained in concealment couples resonantly with the experiences of the Liddle family. Recall that Liddle did not encounter any actual soldiers when her outhouse was declared illegal. Rather, her family returned to the presence of a note placed — one almost wishes to say surreptitiously — while they were in the woods resource gathering. Compare this experience with Willis's stories of elders being forcibly removed and the frequent refrain of guns being leveled at berry pickers that dotted my conversations with older Haida who had lived through the Base era. For Liddle's family, there was an almost ghostly quality to military presence, making its claims known without direct, human interaction.

Following Stoler, however, we must remain clear that the performance of a disappearance, or the assumption of a ghostly quality, does not actually constitute absence. The military personnel who put that note on the outhouse were not ghosts, and they maintained the same capacity for violence they had with an overt presence. Instead, Liddle's experiences show us that what proves most durable under the conditions of colonial occupation are not the material sedimentations of the military nor their potentially unsettling social relations with Indigenous civilians. What is durable is the maintenance of domination itself. This truth was not lost on Liddle. "Regardless of the DND having a 'lease' or 'license of operation' over that area," Liddle wrote to the local paper in response to the notice,

for the radio station or "elephant trap" or whatever you want to call it I am hereby giving notice that as a Haida I will not be pushed out, or bullied out of accessing an area that my family and generations before me have accessed for pleasure, and for food gathering! . . . Your "occupation" of my traditional lands has altered their appearance and use on a much larger scale than my little outhouse ever will! Your "golf course" has ruined our berry picking areas, and our access to a large swath of land that covers acres. I think that we have a bigger issue that needs to be discussed, not only with myself, but with our community as a whole. (Peerless 2013)

Liddle regarded the note on her outhouse as an extension of the Base itself, an instrument of settler violence and domination on Haida traditional territory — altering Haida land and restricting Haida access to resource-gathering areas used for 
generations. The ruins of CFS Masset did not mean, then, that the military was gone. Really, they did not mean anything at all for Liddle, since the "issue" that the Base had always represented remained ongoing.

We should take Liddle seriously when she invokes a "bigger issue" in need of discussion. Indeed, one could extend her critique to the mechanisms of settler colonialism more broadly - the occupation of Indigenous territories via legal means that ignore Indigenous claims to sovereignty and land title, the transformation of the lands and waters in sometimes devastating ways that ignore long histories of Indigenous rights, resource practices, and care for human and nonhuman beings, and, of course, the many different means of violence through which colonial domination is effectively maintained (cf. Wolfe 2006; Kauanui 2016). The military is metonymy here, the literal occupying force that instantiates and undergirds settler colonialism at its most basic level.

Military violence lies at the heart of settler colonialism. Consider, for instance, Audra Simpson's (2014) reflections on the so-called Oka Crisis, which occurred when a country club in the Quebec town of Oka extended its golf course onto the land of the Mohawk community of Kanehasatà:ke in the early 1990s. After months of peaceful protest to this latest iteration of centuries of land expropriation produced little result, as Simpson (2014, 151-52) narrates, "the Warrior society convened at Kanehasatà:ke with AK-47 assault rifles," intending to block the theft of their land. In response, Quebec's provincial government and the federal government of Canada deployed a total of 2,650 troops to end what settler media had declared a "crisis." There were only fifty-five Mohawk warriors. "This," writes Simpson (2014, 151-52), "was the most unambiguous form of exceptional relations, that of warfare." Similar shows of violence have occurred throughout Canadian history, just as they continue into the present, as the 2018 and 2019 deployments of the Royal Canadian Mounted Police (RCMP, armed with assault rifles, sniper rifles, and helicopters) to "remove" Wet'suwet'en elders and activists from their own land demonstrates (e.g., Dhillon and Parrish 2019; Nikiforuk 2019; NetNewsLedger 2020).

This colonial capacity for immediate and overpowering military intervention on Indigenous lands and in Indigenous communities undergirds the many "diverse forms of violence - from cultural repression to labour coercion to sexual exploitation," as Penelope Edmonds and Amanda Nettelback $(2018,6)$ put it, that together constitute imperial and colonial domination in settler contexts. ${ }^{18}$ Dispossession, as Leanne Betasamosake Simpson (2017, 41) writes of her Michi Saagii Nishnaabeg Nation, "was accomplished and is maintained through land theft as a result of un- 
ethical treaty making and the murdering, disappearing, assimilating and erasing of Michi Saagii Nishnaabeg bodies and presence from the north shore of Ontario." All of these are essentially violent processes, but, echoing both Max Weber (1994) and Giorgio Agamben (1998), it is the colonial monopoly on putatively legitimate violence that makes them possible by rendering Indigenous bodies perpetually vulnerable as Indigenous bodies, bodies that always carry the potential to be excluded from the circle of settler society and legitimately killed as its inconvenient excess (A. Simpson 2014, 152-57). Or, put another way, the distinctively military capacity to, at any moment, slip Indigenous subjects from the category of "(partial) citizen" to "enemy" is one means through which colonial legitimacy is produced in the first instance, allowing military interventions to be read by settler citizens as the maintenance of civil order rather than the exertion of colonial (and colonizing) force.

What the Oka crisis, the attacks on Wet'suwet'en protestors, and the many other cognate moments in which police and military force are deployed to address Indigenous protest have in common are their visibility. They constitute flashpoint moments, the overt expressions of military violence that remind both Indigenous and settler citizens of the settler state's capacity to enforce its territorial authority. To remain marked as "exceptional," however, such violence must become invisible in the course of everyday life. Here is where the particular configuration that was CFS Masset can give us specific insights into the broader nature of colonial occupation. Unlike an RCMP raid on an Indigenous camp, the Base was not aimed at the Haida community. As a naval listening station, it was focused on the Cold War, and we could understand the everyday ways in which it happened to dominate Indigenous territories and attempted to regulate Indigenous lives as a mere epiphenomenon of regular military practice. The Base, in other words, was not explicitly commissioned to dominate Indigenous populations; it did so as a matter of course. And this mundane quality, this everyday domination, erases itself even as it proceeds, even as it eventually erodes even the possibility for alternative modes of relationality.

And, of course, the Base itself proved exceptional rather than typical as a military base. It was meant to be "open-concept," after all, a striking move away from the model of army facilities as spaces of fear surrounded by barbed wire fences. Yet, as we have seen, this very openness caused tremendous insecurity. Both the Base's facilities and its personnel policies undercut the idea that anything could be durable in the military's relationship to Haida Gwaii except for the simple fact of occupation itself. And for those purposes, a base in the center of town 
simply proved far too visible. Ruins and ghosts do a far better job concealing the ongoing conditions of occupation to which Liddle so effectively pointed in her letter (cf. Leathem 2019). ${ }^{19}$

\section{“THEY SURE THOUGHT WE'D MISS THEM"}

One night, over dinner with Haida friends in their house in the Village of Masset, which was once a private married quarter, we began to chat about the legacy of the Base and my research. After reflecting on her own experiences over many years of engagement with the personnel of CFS Masset, Primrose Adams, elder and matriarch, responded pithily: "They sure thought we'd miss them. We didn't."

There are many ways to read Adams's quip. One, as the Liddle family discovered, would be quite literal — how can one miss the military when its members never actually left? But we might also see in Adams's statement an almost sympathetic understanding that military personnel, too, had engaged in relationship-building with Haida, that they, too, felt the ambivalences of bonds "not built to last." As I have argued, the dangerous possibility of military-Indigenous relationships is precisely mutuality, the ways in which military personnel could find themselves in relationships with Haida people that entailed both care and respect. Even beyond the unsettling promise of such relationships, however, the idea that at least some military personnel hoped to be appreciated for the work they understood themselves doing for the Haida community, even if that work was ultimately Janus-faced, would not be particularly surprising. Adams nods to this in her quip, positioning the military as actively desirous of affective ties, of wanting to be missed. For non-Haida, just as much as for Haida, relationships are meant to be durable even when, structurally, they are foreclosed. Hence the hope that Adams reads into the military officers, "they sure thought we'd miss them." In this we see the ways in which the military's policies also do a kind of affective violence to its own personnel, preventing them from building relationships with Haida people even if they might wish to do so. All that is left is for them to hope to be missed.

Ruination, particularly in Navaro-Yashin's (2009) reading, is inextricable from loss. What has been lost on Haida Gwaii is not the violence of military occupation. Such violence cannot be escaped under the ongoing structures of settler colonialism. But what the ruins of the Base, literal and figurative, represent is the loss of the potential for something otherwise to colonial hegemony, the potential for relationships that might be more entangled, more complex, perhaps even relationships that could open up space for dialogue, for mutuality. This loss is worth 
mourning, at least for Montgomery and those Haida who share his ambivalence about the Base and its legacy. And, one imagines, it might be worth mourning for those military personnel who did wish to make Haida Gwaii home, for whom the golf course, the swimming pool, and the other transformations that CFS Masset brought with it also formed part of making the islands into a more suitable space for cosmopolitan Canadian military officers.

Adams, by contrast, expressed no ambivalence in our conversation. There was an affective charge, a sharpness, to her quip that written text does not convey perfectly: "They sure thought we'd miss them. We didn't." Adams here claims the power to reject, to refuse, an ongoing affective relationality with the military, and she claims it on behalf of her Haida community more generally. Regardless of what the military might want, they were an aggressive presence on Haida land that brought changes neither asked for nor necessarily desired. For Adams, who experienced Haida Gwaii's entire military era over the course of the twentieth century, there is nothing worth missing, either by her or by Haida people more generally. While she hints that military personnel might regret this loss even though they engendered it, Adams feels certain that the Haida community has no reason to regret the loss of relationality with the forces of occupation. Indeed, as the continuing pseudo-phantasmic presence of military personnel on Haida Gwaii reminds us, the promise of relationality, of an open-concept military base embedded in the community, was always illusory, always a means of disguising the violence of settler colonialism. Even the most sincere of affects are eroded by this ongoing violence.

\begin{abstract}
This article explores the afterlife of a military base on the islands of Haida Gwaii, unceded territory of the Indigenous Haida Nation. Canadian Forces Station Masset was officially decommissioned in 1997, its buildings abandoned by Canada's armed forces. The understanding of both Haida and their settler neighbors was thus that the army was gone, leaving only ruins and ambivalent affects in its wake. Yet the military had not actually left; rather, it remained in concealment, continuing to monitor the territory it had occupied. At work in this strange juxtaposition of absence and presence, I argue, is the deliberate production of a paradox, a constitutive contradiction that serves to reinforce the structures of settler domination even as it mitigates the visible presence of the forces of occupation. The affects of ruination engendered by the military's departure, I contend, form part of these processes of settler concealment and deception. [settler colonialism; Indigeneity; ruination; militarism; occupation]
\end{abstract}




\section{NOTES}

Acknowledgments First, I would like to acknowledge the generous assistance and support of the Old Massett Village Council and the Village of Masset during my research. My gratitude to friends and colleagues on Haida Gwaii is, as ever, incalculable, with particular how.aas owed here to Helen Davis, the late Agnes Davis, Sherri Burton, Alfred Adams, the late Primrose Adams, Leslie Bellis, and Craig and Karen Russ. I am also most grateful for the exceptional feedback and suggestions on the article from J. Kēhaulani Kauanui, Bruce Miller, Margot Weiss, Eric Hirsch, Hannah Chazin, Andrea Ford, Meghan Morris, and Xiao-bo Yuan. Hilary Morgan V. Leathem also provided endless commentary, feedback, and exceptionally helpful suggestions, and my love and gratitude to them is, as always, profound. The article further benefited from the feedback of four anonymous peer reviewers, the patience, suggestions, and editorial guidance of Christopher T. Nelson, the excellent copy editing of Petra Dreiser, and the fantastic editorial support of Jessica Lockrem, to whom I also owe my thanks. Earlier versions of this article were presented at American Anthropological Association meetings, Wesleyan's Division II Luncheon Seminar, and the University of Victoria Anthropology Department's Anthropology Colloquium Series; I'm most grateful for these conversations. Finally, portions of this research were carried out with the support of the Wenner-Gren Foundation for Anthropological Research, the American Philosophical Society, the Canadian Museum of History, Wesleyan University, and the University of Chicago, all of whom I would like to thank sincerely.

1. Gordillo (2014, 6-11) opposes this way of thinking about rubble with more conventional heritage logics that prioritize the preservation of "ruins" as sacrosanct spaces (cf. Leathem forthcoming).

2. All names in this essay are pseudonymous unless quoted from a public context or identification was specifically requested.

3. This article draws from the fieldwork I have been doing on Haida Gwaii since 2010, with a sustained period of full-time residence between 2012 and 2013, though most of the conversations I bring forward here took place over a number of summers between 2015 and 2019. While I do not have the space here to fully address my own positionality as a settler researcher working with an Indigenous community, see Weiss (2018, 21-25) for a detailed discussion of my own commitment to relational, anticolonial, and dialogic research practices and ethics.

4. The Haida scholar Jisgang Nika Collison $(2011,17)$ is explicit on this point, arguing that "the potlatch is our [Haida] legal system," a means through which territorial claims can be evaluated and verified.

5. The refusal to acknowledge Aboriginal Title in British Columbia and the absence of historical treaties are some of the defining features of the province's distinctive settler-colonial history. See Cole Harris's (2002) Making Native Space for a detailed discussion of the logics that justified the Crown's seizure of Indigenous land although even Britain's own Royal Proclamation of 1763 commanded the king's subject to extinguish Aboriginal Title before taking possession of Indigenous territories. Note, too, that Aboriginal Title is itself a problematic concept, a colonial reframing of the idea that Indigenous communities had preexisting territorial rights prior to colonial settlement (Asch 1997). It should not be considered identical to Haida understandings of sovereignty as vested traditionally in the individual clans and their leadership and negotiated through ceremony. More recently, the claim to Haida sovereignty has been taken up by the Council of the Haida Nation on behalf of the Haida Nation as a whole (see Weiss 2018, 2020).

6. There is also the impact of the so-called Davis plan on Indigenous fisheries on Haida Gwaii (and throughout British Columbia), which severely limited the ability for Indigenous fishers to participate even in relatively small-scale commercial fishing (see Newell 1993).

7. The language of "open-concept" was drawn directly from open-concept architecture, emphasizing notions of space and freedom in social and spatial design. The application 
of these values to military design is ironic, to say the least, especially given the ways that military presence fundamentally constrained Haida mobility on their own ancestral territories.

8. This is another irony of the "open-concept" military base - as the barracks were positioned within the Village of Masset, it meant that the military police patrolled the town itself, though ostensibly only when issues involving the military occurred. Yet this boundary proved porous.

9. While many Haida worked for the Base in service positions, I am not aware of many individuals who joined the Canadian military themselves. This differentiates the social dynamics from spaces such as Hawai'i, as Ty P. Kāwika Tengan (2008) has explored, in which military service marked a significant way through which Indigenous masculinity could be articulated under ongoing settler-colonial conditions.

10. Note that during most of the twentieth century - and certainly during the period in which Armstrong was growing up-Haida women married to non-Haida men were stripped of their Indian status and could no longer reside in Old Massett. Many chose to live in the Village of Masset with their spouses. The children of these marriages, likewise, did not have status until Bill C-31 brought substantial changes to Canadian Indian law in the 1980s (Weiss 2018, 6; see A. Simpson [2014] for a discussion of the impact of these changes in a Mohawk context.)

11. We might also consider Patrick Wolfe's (2013) suggestion that "binarism" itself might result from settler subjecthood.

12. These tensions were not limited to Haida of Fred Willis's age, who were in their twenties and thirties during the Base's heyday. As the journalist Ian Gill (2010) recounts, some Haida elders supported the military, at least on the surface; Gill tells the story of young Haida protestors being scolded by their elders for interfering with a ceremony in which the military was given Masset's key to the city in the early 1970s, though whether this represented genuine approval of the military on the part of those elders or a concern with respect and decorum is not entirely clear in Gill's account. Likewise, while I did not collect systematic data on this point, a number of the Haida individuals I knew who had previously worked for the military also held relatively high ranks within clan hierarchies, which suggests, at the very least, that the resources the military provided could be (and often were) repurposed for internal Haida ends.

13. See Joanne Barker (2011) for a detailed discussion of the naturalization of colonial gendered norms in different U.S. contexts, and Kauanui (2018) for a discussion of similar issues in Hawai' $i$.

14. While I note below that the sense of the military's departure was felt as quite sudden by many in the Haida and settler communities, interlocutors working at the Base during that time described a more gradual winding down of military operations, marked especially by decreases in active personnel and training activities. The end of the Cold War in the late 1980s simply meant less need for a well-staffed training base so close to Russian waters.

15. The funds were a combination of assets, financial reserves and, perhaps most interestingly, a lump sum given to GMDC to manage or demolish the military's former buildings in lieu of their demolition by the Department of Defense. This arrangement meant, in part, to preserve the rec center and, especially, the swimming pool. It was also at this point that the military sold the private married quarters to the Village of Masset, which in turn resold them as private real estate.

16. This is also true, and remains true, of officers deployed to Masset's RCMP station.

17. This sense of military invisibility, I was recently told by a military officer, contrasts sharply with the military's own understanding of their continuing presence in Old Massett, which consists of a small crew who operate the radio apparatus, now renamed CFS Leitrim Detachment Masset. And yet, the sense that the military was at best gone, at worst hiding, was almost ubiquitous in both communities during my time there. Here again the performative work of ruination and concealment works to disavow the social sense of an ongoing military presence. 
18. It is not a coincidence, shifting briefly from one settler colony to another, that the United States Armed Forces still refers to enemy territory as "Indian country" (Lyons 2010, 17-18). Indeed, “The early US military," notes Catherine Lutz (2009, 10), "became entwined with the frontier project of removing Indians from the land and protecting colonists who settled there. In this sense, every Western fort - and there were 255 of them — was a foreign military base, established on native land during the Indian campaigns and the Mexican-American war." This formed an important precedent, Lutz argues, for American overseas expansion, which similarly operated through a dense network of territorializing U.S. bases on foreign soil.

19. Even the "elephant cage" itself seems to have lost at least some of its significance as a military facility for some of Masset's residents, as the marketing of a gourmet coffee by local non-Haida entrepreneurs under the brand Elephant Cage Coffee Roasters attests (see the Elephant Cage Coffee Roasters website, www.elephantcagecoffee.com, accessed July 24, 2020).

\section{REFERENCES}

Agamben, Giorgio

1998 Homo Sacer: Sovereign Power and Bare Life. Translated by Daniel Heller-Roazen. Stanford, Calif.: Stanford University Press.

Asch, Michael, ed.

1997 Aboriginal and Treaty Rights in Canada: Essays on Law, Equality, and Respect for Difference. Vancouver: UBC Press.

Barker, Joanne

2011 Native Acts: Law, Recognition, and Cultural Authenticity. Durham, N.C.: Duke University Press.

Bell, Lucy Sdaahl K'awaas

2016 “Xaad Kilang T'alang Dagwiieehldang: Strengthening Our Haida Voice.” Master's thesis, University of Victoria.

Collison, Nika Jisgang

2011 "Xaayda XaadaGa GiiahlGalang, Story of the Haida People." In That Which Makes Us Haida: The Haida Language, edited by Jusquan Amanda Bedard and Nika Collison Jisgang. Skidegate, British Columbia: Haida Gwaii Museum Press.

Dhillon, Jaskiran, and Will Parrish

2019 "Exclusive: Canada Police Prepared to Shoot Indigenous Activists, Documents Show.” Guardian (UK), December 20. https://www.theguardian.com/ world/2019/dec/20/canada-indigenous-land-defenders-police-documents.

Edmonds, Penelope, and Amanda Nettelbeck, eds.

2018 Intimacies of Violence in the Settler Colony: Economies of Dispossession around the Pacific Rim. London: Palgrave Macmillan.

Enloe, Cynthia

2000 Maneuvers: The International Politics of Militarizing Women's Lives. Berkeley: University of California Press.

Gill, Ian

2010 All That We Say Is Ours: Guujaaw and the Reawakening of the Haida Nation. Vancouver:

Gordillo, Gastón R. Douglas and McIntyre.

2014 Rubble: The Afterlife of Destruction. Durham, N.C.: Duke University Press.

Harris, Cole

2002 Making Native Space: Colonialism, Resistance, and Reserves in British Columbia. Vancouver: UBC Press.

Kauanui, J. Kēhaulani

2016 “'A structure, not an event': Settler Colonialism and Enduring Indigeneity." Lateral 5, no. 1. https://csalateral.org/issue/5-1/forum-alt-humanities-settlercolonialism-enduring-indigeneity-kauanui/. 
2018 Paradoxes of Hawaiian Sovereignty: Land, Sex, and the Colonial Politics of State Nationalism. Durham, N.C.: Duke University Press.

Kierans, Ciara, and Kirsten Bell

2017 "Cultivating Ambivalence: Methodological Considerations for Anthropology." HAU: Journal of Ethnographic Theory 7, no. 2: 23-44. https://doi.org/10.14318/ hau7.2.006.

Leathem, Hilary Morgan

2019 "Manifestations That Matter: A Case of Oaxacan Ruin Possession.” Archaeological Review from Cambridge 34, no. 2: 92-110. https://doi.org/10.17863/CAM.59741.

Forthcoming "Heritage (Dis)possessed: Haunting, Theft, and the Making of Monumental History in Oaxaca, Mexico.” PhD Dissertation, Department of Anthropology,

Lutz, Catherine University of Chicago.

2002 Homefront: A Military City and the American Twentieth Century. With photographs by elin o'Hara slavick. Boston: Beacon Press.

Lutz, Catherine, ed.

2009 The Bases of Empire: The Global Struggle against U.S. Military Posts. New York: New York University Press.

Lyons, Scott Richard

2010 X-Marks: Native Signatures of Assent. Minneapolis: University of Minnesota Press.

McMullen, Frank Francis Gerald

1998 "When You Come to a Fork in the Road Take It: Negotiating Crisis and Transition in a Northern Village." Master's thesis, University of Northern British Columbia.

Navaro-Yashin, Yael

2009 "Affective Spaces, Melancholic Objects: Ruination and the Production of Anthropological Knowledge." Journal of the Royal Anthropological Institute 15, no. 1:

NetNewsLedger 1-18. https://doi.org/10.1111/j.1467-9655.2008.01527.x.

2020 "RCMP Patrol Wet'suwet'en Cultural Site with Assault Rifles." NetNewsLedger, June 29. http://www.netnewsledger.com/2020/06/29/rcmp-patrol-wetsuwetencultural-site-with-assault-rifles/.

Newell, Dianne

1993 Tangled Webs of History: Indians and the Law in Canada's Pacific Coast Fisheries. Toronto: University of Toronto Press.

Nikiforuk, Andrew

2019 "From the Archives: When Indigenous Assert Rights, Canada Sends Militarized Police.” Tyee, January 17. https://thetyee.ca/Analysis/2019/01/17/IndigenousRights-Canada-Militarized-Police/?fbclid=IwAR2LCo5MaSyinmDYyXrWlptZK

Peerless, Sarah

$$
\text { ZBeGN-KgRRsNusLPvr00KeWx2HDlEyYV9s. }
$$

2013 "Family Questions Trespass Notice from Masset Military." Haida Gwaii Observer, July 15. http://www.haidagwaiiobserver.com/news/family-questions-trespass-

Schober, Elisabeth notice-from-masset-military/.

2016 Base Encounters: The US Armed Forces in South Korea. London: Pluto Press.

Simpson, Audra

2014 Mohawk Interruptus: Political Life across the Borders of Settler States. Durham, N.C.: Duke University Press.

Simpson, Leanne Betasamosake

2017 As We Have Always Done: Indigenous Freedom through Radical Resistance. Minneapolis: University of Minnesota Press.

Stearns, Mary Lee

1981 Haida Culture in Custody: The Masset Band. Seattle: University of Washington Press.

Stoler, Ann Laura

2016 Duress: Imperial Durabilities in Our Times. Durham, N.C.: Duke University Press. 
Tengan, Ty P. Kāwika

2008 Native Men Remade: Gender and Nation in Contemporary Hawai'i. Durham, N.C.: Duke University Press.

Trouillot, Michel-Rolph

1995 Silencing the Past: Power and the Production of History. Boston: Beacon Press.

Weber, Max

1994 “The Profession and Vocation of Politics." In Weber: Political Writings, edited by Peter Lassman and Ronald Speirs, 309-69. Cambridge: Cambridge University Press.

Weiss, Joseph

2018 Shaping the Future on Haida Gwaii: Life Beyond Settler Colonialism. Vancouver: University of British Columbia Press.

2020 "Giving Back the 'Queen Charlotte Islands': The Politics of Names and Naming between Canada and the Haida Nation." Native American and Indigenous Studies 7, no. 1: 62-86. https://doi.org/10.5749/natiindistudj.7.1.0062.

Wolfe, Patrick

2006 "Settler Colonialism and the Elimination of the Native." Journal of Genocide Research 8, no. 4: 387-409. https://doi.org/10.1080/14623520601056240.

2013 "Recuperating Binarism: A Heretical Introduction." Settler Colonial Studies 3, no. 3/4: 257-79. https://doi.org/10.1080/2201473X.2013.830587. 